\begin{tabular}{|l|l|l||}
\hline \multicolumn{2}{|c|}{ PublisherInfo } \\
\hline \hline PublisherName & $:$ & BioMed Central \\
\hline \hline PublisherLocation & $:$ & London \\
\hline \hline PublisherImprintName & $:$ & BioMed Central \\
\hline \hline
\end{tabular}

\title{
Plague doesn't protect
}

\begin{tabular}{|l|l|l||}
\hline \multicolumn{2}{|c|}{ ArticleInfo } \\
\hline \hline ArticleID & $:$ & 4913 \\
\hline \hline ArticleDOI & $:$ & $10.1186 /$ gb-spotlight-20040212-01 \\
\hline \hline ArticleCitationID & $:$ & spotlight-20040212-01 \\
\hline \hline ArticleSequenceNumber & $:$ & 265 \\
\hline \hline ArticleCategory & $:$ & Research news \\
\hline ArticleFirstPage & $:$ & 1 \\
\hline \hline ArticleLastPage & $:$ & 3 \\
\hline \hline & & RegistrationDate : 2004-2-12 \\
\hline ArticleHistory & $:$ & OnlineDate \\
\hline \hline ArticleCopyright & $:$ & BioMed Central Ltd2004-12 \\
\hline \hline ArticleGrants & $:$ & \\
\hline \hline ArticleContext & $:$ & 130594411 \\
\hline \hline
\end{tabular}


The unusual genetic frequency and distribution of a deletion mutation in the chemokine receptor gene CCR5 - providing protection against HIV infection and AIDS - is thought to have been selected by conferring resistance to the Black Death during the Middle Ages. In the February 12 Nature, Joan Mecsas and colleagues at Stanford University report that CCR5 knockout mice are not protected against Yersinia pestis infection after all, forcing a rethink of the hypothesis (Nature 2004, 427:606).

Steve O'Brien, head of the Laboratory of Genomic Diversity at the National Cancer Institute and proponent of the plague selection hypothesis, who was not involved in the study, told us, "Something in the past started killing millions of people, and that thing, whatever it was, was probably slowed down in people who carried CCR5 [mutation in] either one or two copies, and that slowing down probably allowed that gene to rise up in frequency, not once but many times over the last few thousand years."

"We were able to back-calculate how long it had been since the last strong selective pressure, and that came out to be about 30 generations, or roughly 700 years, ago, and that of course was right smack in the Middle Ages, in the middle of the biggest epidemic and devastation and plague in recorded history: the Black Death," said O'Brien.

Don Mosier, professor in the Department of Immunology at the Scripps Research Institute in California, leading the study, told us, "We're part of a group developing CCR5 blockers as a potential AIDS therapy, so we were interested in this question from the point of view that perhaps infection with the plague organism - a bacterium not a virus - somehow depended upon CCR5, and the same blocking agents would have a new use: which would be protecting against a bioterrorism use of the plague organism."

Defending the hypothesis, O'Brien said, "I think that the results were rather clean, but I think the thing that I am still cautious about is the interpretation. There's a body of literature that suggests that the mechanism of pathogenesis in mice and in humans is different, and if that's the case, then you would expect a negative result even if Yersinia was the cause of the human selective pressure.

"We're not quite at the point yet where I think we can put this story to bed," he added.

Mosier explained that the difference is that humans get two forms of the plague, while mice get only one; a lethal systemic infection. In humans, the initial infection from a rodent flea carrying the disease in its gut results in massive swelling of the lymph nodes, or buboes (hence bubonic plague), which has a lethality of 15 to $30 \%$. Secondary infection with pneumonia results in pneumonic plague, an airborne infection that is almost always fatal.

"For Steve O'Brien to be right, the CCR5 mutation would have to increase your ability to survive bubonic plague, the initial flea-to-human transmission, but not impact survival after pneumonic plague," Mosier told us.

"There is no suggestion that we can use CCR5 blockage to protect against the plague... After we submitted, there was a modeling study from UC Berkeley that suggested that smallpox might have more 
selective power as a disease for protective mutation. So we are planning to test that idea. So the whole idea is resurrected but transferred to a different disease: smallpox rather than plague," Mosier said.

\section{References}

1. Nature Immunology Chemokine Web Focus, [http://www.nature.com/ni/special_focus/chemokine/]

2. Nature, [http://www.nature.com/nature]

3. Department of Microbiology and Immunology, Stanford University School of Medicine, [http://cmgm.stanford.edu/micro/]

4. Laboratory of Genomic Diversity, National Cancer Institute, [http://rex.nci.nih.gov/lgd/ front_page.htm]

5. Mosier Laboratory, [http://www.scripps.edu/imm/mosier/]

6. Evaluating plague and smallpox as historical selective pressures for the CCR5-Delta $32 \mathrm{HIV}$ resistance allele.

This PDF file was created after publication. 